\title{
Dampak Pengembangan Buku Cerita Bergambar Untuk Anak Usia Dini
}

\author{
Dellya Halim, Ashiong Parhehean Munthe \\ dellyahalim02@gmail.com, ashiong.munthe@uph.edu \\ Pascasarjana FIP Universitas Pelita Harapan, Guru Sekolah St. Theresia Jakarta \\ Pascasarjana FIP Universitas Pelita Harapan
}

The Impact Of Picture Storybook For Early Childhood

\begin{abstract}
Development in the world of education is very necessary. Innovation and creativity are needed to update and develop existing products or those that want to be developed according to changing times. Picture books that emphasize character values in accordance with the vision and mission of one Kindergarten located in Central Jakarta are very urgent to develop because, at the school, there is no character education book with the value of servite et amate. This was revealed by the teacher through an interview. Based on observations, it was also found that there was indeed no character education book that was in accordance with the school's vision and mission. Picture storybooks are interrelated books between images and text which are the unity of a story. This study uses the research and development method, with the ADDIE model. The data collection techniques used were instrument validation sheets and feedback tests for children. Through the 4 stages of evaluation from experts, the results of the final validation from design experts, linguists and content experts/material get a value of $100 \%$ with a very feasible category. From the results of the trials conducted on 2 different classes of treatment, it was shown that this story book illustrated with Layanilah and Cintailah has benefits for kindergarten children. This is evidenced by the mean obtained from the class without the product, namely four questions that get the highest mean value. The other three questions get a low mean. The illustrated storybooks has a positive impact on the understanding of this school, especially in terms of knowing examples of actions that are consistent with the values of servite et amate.
\end{abstract}

Keywords: Early Childhood, Picture Storybook, Impact, Development

Received date: 3 Juli 2019

Article Info

Revised date: 31 Agustus 2019 Accepted date: 19 September 2019

\section{PENDAHULUAN}

Di zaman globalisasi ini, sebuah penelitian dan pengembangan dalam dunia pendidikan perlu terus ditingkatkan. Inovasi dan kreativitas diperlukan untuk memperbarui dan mengembangkan produk yang sudah ada atau yang ingin dikembangkan sesuai perubahan zaman. Tentunya dengan memperhatikan karakteristik peserta didik. Van den Akker, dkk (2006), menggambarkan bahwa penelitian pengembangan berdasarkan pada dua tujuan yaitu pengembangan prototipe produk dan perumusan saran-saran metode untuk pendesainan dan evaluasi prototipe dari produk itu. Produk yang dimaksud dapat berupa buku ajar, video, software, maupun metode.

Dalam PP nomor 19 tahun 2005 Pasal 20, diisyaratkan bahwa guru diharapkan dapat mengembangkan materi pembelajaran secara mandiri. Guru merupakan praktisi pendidikan sekaligus peneliti yang membuat keputusan berdasarkan penelitian guna pengembangan pengajaran yang lebih baik (Borg, W., et al, 2015). Pada dasarnya, guru juga diharapkan dapat mengembangkan sumber belajar yang dapat mendukung pengembangan kompetensi siswa termasuk pengetahuan mereka. Seperti yang dikemukakan oleh Nomleni dan Manu (2018: 219-230), bahwa media dan alat peraga yang dikembangkan oleh guru dapat meningkatkan kemampuan pemahaman konsep pada siswa. Ada beberapa macam model rancangan penelitan dan pengembangan (Reseach and Development) yang bisa digunakan dalam dunia pendidikan, antara lain Borg and Gall, Dick and Carey dan ADDIE. Pengembangan yang dilakukan berdasarkan kepada penelitian serta kepada analisis kebutuhan.

Sebuah produk pengembangan yang dapat dilakukan terus menerus untuk anak usia dini salah satunya adalah buku cerita bergambar. Buku cerita bergambar pun merupakan proses perkembangan 
dan perpaduan dari buku berupa teks dan gambar yang sifatnya visualisasi. Menurut Crowther (1995), buku cerita pada dasarnya merupakan salah satu buku teks bacaan yang dibuat untuk proses pembelajaran. Sedangkan gambar memiliki manfaat antara lain dapat menarik perhatian, unik, hal - hal yang bersifat abstrak dapat diperjelas, serta mampu mengilustrasikan suatu proses (Hackbarth dalam Uno, 2011:128). Gambar tersebut akan mempermudah anak untuk membayangkan isi dan alur cerita yang disampaikan. Dengan demikian, buku cerita bergambar adalah buku yang saling terkait antara gambar dengan teks yang merupakan kesatuan sebuah cerita (Mitchell 2002:87). Karakteristik buku cerita bergambar untuk anak-anak adalah buku dengan gambar dan teks yang bersama-sama, menceritakan sebuah kisah, dengan tema yang sesuai untuk anak-anak (Malu, 2013).

Kehadiran buku cerita bergambar menjadi sesuatu yang umum dan sangat disukai oleh anakanak. Dipakai juga sebagai salah satu sumber pembelajaran. Menarik sebagai sumber pembelajaran, karena cerita dapat divisualisasikan dengan gambar dan warna-warna yang menarik sesuai dengan alur dan latar cerita.

Anak Usia Dini adalah anak yang berada pada rentang usia 0-5 tahun. Pada masa Usia Dini disebut juga sebagai golden age atau masa keemasan. Pada masa keemasan tersebut, anak mulai peka atau sensitif terhadap berbagai rangsangan dan sangat menyukai buku cerita dengan gambar-gambar yang menarik. Usia Dini juga dikenal sebagai masa awal, dan mengalami pertumbuhan dan perkembangan yang pesat dalam bidang fisik motorik, sosio emosional, kognitif, bahasa, agama, dan moral. (Hartati 2005:11). Menurut Piaget dalam Berk (2012) bahwa anak usia dini (dalam rentang 45 tahun) berada pada tahap pra operasional konkret. Anak Usia Dini menurut Suyanto (2005: 7) sedang dalam masa pertumbuhan baik secara fisik maupun secara mental. Pada usia ini, anak juga tidak hanya mengalami perkembangan secara fisik dan motorik saja, tetapi juga mengalami pertumbuhan dan perkembangan secara kepribadian, watak, emosional, intelektual, bahasa, dan moral secara pesat. Pertumbuhan dan perkembangan saraf otak sudah dimulai sejak dalam kandungan hingga pasca kelahiran. Seluruh sel saraf otak akan terus mengalami perkembangan hingga "sempurna" yang diiringi perkembangan fisik dan mental juga.

Buku cerita bergambar memiliki dampak yang baik untuk anak usia dini. Hsiao, Yuan dan $\mathrm{Yu}$ Shih (2015:14-23) dalam penelitiannya menemukan bahwa pengetahuan tentang lingkungan dapat ditingkatkan dalam diri anak-anak lewat buku cerita bergambar, terutama karena berdampak pada kehidupan sehari-hari mereka. Retnowati, dkk (2018:89-95) melakukan penelitian dengan tujuan untuk mengetahui efektivitas gambar dalam membaca buku cerita untuk meningkatkan kebaikan pada anak. Hasilnya disimpulkan bahwa ada perbedaan yang signifikan dari nilai rata-rata tes dan pengukuran posttes kebaikan. Itu artinya membaca buku bergambar secara efektif dapat meningkatkan kebaikan anakanak berusia 5-6 tahun.

Penelitian dan pengembangan terkait buku cerita bergambar untuk anak usia dini dilakukan untuk menjawab kebutuhan sekolah dan guru-guru dalam mengimplementasikan visi dan misi sekolah melalui cerita yang relevan bagi anak usia dini. Berdasarkan hasil wawancara dengan Kepala Sekolah serta guru-guru, membutuhkan buku cerita bergambar yang berisi nilai-nilai karakter yang sesuai dengan visi misi sekolah. Selain itu, buku cerita yang tersedia saat ini hanya menyangkut satu atau dua nilai yang sesuai dengan karakter servite et amate. Buku cerita bergambar juga dibutuhkan karena sebagian besar yang dilakukan oleh para guru saat bercerita adalah menggunakan buku cerita bergambar. Buku cerita bergambar membuat anak bisa menyentuh langsung dan melihat buku tersebut secara langsung. Sejauh ini buku cerita yang digunakan adalah buku cerita yang hanya memiliki satu atau dua nilai yang sama dengan nilai-nilai servite et amate. Guru mengalami kesulitan untuk menemukan buku tentang nilai karakter yang sesuai dengan keyakinan agama Katolik. Toko buku kristiani yang mengeluarkan buku cerita berlandaskan agama Katolik kebanyakan bahasanya kurang sesuai untuk anak usia dini. Dengan demikian, pengembangan buku cerita bergambar yang berisi nilainilai yang sesuai dengan visi misi sekolah diupayakan untuk menjawab kebutuhan di sekolah ini.

Dari latar belakang di atas, rumusan masalah dalam penelitian ini adalah 1) bagaimana proses analisis dilakukan dalam menemukan solusi untuk menjawab kebutuhan, 2) bagaimana merancang, mengembangkan, mengimplementasikan serta mengevaluasi kebermanfaatan dari buku cerita bergambar untuk anak usia dini. 


\section{KAJIAN PUSTAKA}

\section{a) Peranan Buku Cerita Bergambar}

Menurut Piaget dalam Mueller (2006:7) mengatakan perkembangan kognitif anak itu dimulai dari yang konkrit menuju abstrak. Hal ini berarti cara berpikir anak masih dibantu oleh benda-benda/ obyek-obyek yang nyata, serta melalui peristiwa yang dialami dan dilihatnya. Buku cerita bergambar dimanfaatkan menjadi sarana pembelajaran bagi anak untuk bisa berpikir dari yang konkrit ke abstrak. Buku cerita bergambar juga lebih mudah untuk pengenalan kosa kata baru yang dibantu dengan ilustrasi gambar. Dengan demikian, anak dapat lebih mudah mengenal kata dan gambar secara jelas. Mereka akan mampu mengingat secara abstrak di dalam pikiran, apabila cerita tersebut diulang kembali.

Peranan buku cerita bergambar menurut Mitchell dalam Nurgiyantoro (2013:159) sangat penting, karena dapat membantu siswa belajar tentang alam, mengenal orang lain dan hubungan yang terjadi dan pengembangan perasaan. Dengan demikian, anak dapat memahami dan menghubungkannya dengan pengalaman pribadinya, menstimulasi imajinasi, memperoleh kesenangan serta keberadaan di tengah masyarakat.

Anak-anak usia sekolah sangat menyukai cerita bergambar menurut Hurlock dalam Faizah (2009:254), karena beberapa alasan diantaranya, yaitu: (1) lewat cerita anak mendapat kesempatan untuk mengenal masalah pribadi dan sosialnya. Hal tersebut akan membantu anak dalam memecahkan masalah yang dihadapinya; (2) cerita bergambar menuntun imajinasi dan menarik rasa ingin tahu anak; (3) mudah dibaca dan dipahami anak, karena anak yang kurang mampu membaca, dapat memanfaatkan gambar untuk memahami isi ceritanya meskipun belum bisa membaca; (4) buku cerita bergambar sudah umum dan tidak sulit untuk ditemukan; (5) buku cerita distimulus oleh gambar agar anak tertarik membaca; (6) cerita bisa dibuat berbentuk serial, sehingga mendorong rasa penasaran anak; (7) tokoh dalam cerita sering menunjukkan perilaku yang membuat anak-anak berpikir langkah berikutnya dari cerita; (8)karakter tokoh dalam cerita seperti berani, kuat, berwajah cantik/ tampan, sehingga membuat anak menjadikan tokoh andalan; (9) gambar yang ditampilkan dalam cerita penuh warna dan sederhana agar mudah dipahami anak.

Dengan karakteristik anak usia dini yang berada pada tahap pra operasional konkret, maka anak masih membutuhkan benda-benda konkrit untuk membantu proses berpikir. Anak usia dini juga masih sedang mengembangkan keterampilan berpikir dan bahasanya. Dengan demikian, penggunaan buku cerita bergambar merupakan satu cara yang baik dan tepat untuk menyampaikan materi pengetahuan atau pembelajaran agar perkembangan anal lebih optimal.

\section{b) Dampak Buku Cerita Bergambar}

Buku cerita bergambar memiliki dampak yang positif yakni kebermanfaatan untuk anak usia dini. Seperti penelitian yang dikemukakan oleh Evans \& Saint-Aubin (2005), bahwa perhatian visual anak usia dua tahun sangat didukung oleh kosakata yang mereka miliki. Kosakata tersebut membimbing anak-anak ke ilustrasi, dan perhatian pada ilustrasi memandu pemahaman mereka. Montag, et al (2015) juga menemukan bahwa pengulangan menceritakan/membacakan buku cerita bergambar memiliki manfaat dalam pengembangan kosa kata anak. Retnowati, dkk (2018:89-95) melakukan penelitian dengan tujuan untuk mengetahui efektivitas gambar dalam membaca buku cerita untuk meningkatkan kebaikan pada anak. Dengan demikian disimpulkan bahwa ada perbedaan yang signifikan dari nilai rata-rata tes dan pengukuran post-tes kebaikan. Itu artinya membaca buku bergambar secara efektif dapat meningkatkan kebaikan anak-anak berusia 5-6 tahun.

\section{METODE PENELITIAN}

Metode penelitian yang dilakukan ini merupakan proses penelitian dan pengembangan (Research and Development) yang bertujuan untuk mengembangkan buku cerita bergambar. Model pembelajaran yang digunakan dalam penelitian ini adalah model ADDIE. Desain Pembelajaran Model ADDIE merupakan model desain pembelajaran/pelatihan yang bersifat dinamis dan interaktif serta dapat menjadi pedoman dalam membangun perangkat dan infrastruktur program pelatihan yang efektif untuk mendukung kinerja pelatihan itu sendiri. Model ADDIE (Analysis Design Development Implementation Evaluations) memiliki tahapan-tahapan dasar pembelajaran yang efektif, dinamis dan efisien. ADDIE merupakan singkatan dari Analysis (A) yaitu mengidentifikasi masalah berdasarkan analisis kebutuhan yang ditemukan di sekolah serta menemukan produk yang dibutuhkan untuk dikembangkan. Design (D) yaitu menyatakan bentuk kinerja yang diinginkan, mendesain produk, 
serta menentukan metode uji coba yang sesuai yang akan digunakan. Develop (D) yaitu menghasilkan bentuk nyata (buku cerita), memilih media pendukung untuk tujuan yang dinyatakan dari proyek ini, memberikan bimbingan untuk guru dan siswa, serta memperbaiki produk dari hasil revisi (evaluasi formatif). Implement (I) yaitu mempersiapkan lingkungan belajar dan melibatkan siswa, melakukan uji coba pada kelompok kecil, sedang dan besar di dua kelas TK B. Evaluation (E) yaitu untuk menilai kebermanfaatan produk buku cerita serta proses pembelajaran saat uji coba dilakukan (evaluasi sumatif).

Berawal dari Desain Instruksional dan Teori untuk Angkatan Darat AS pada tahun 1950. Kemudian pada tahun 1975 dikembangkan lagi oleh Florida State University untuk digunakan pada semua Angkatan Bersenjata AS. Kemudian oleh para praktisi pendidikan dibuat revisi di pertengahan 1980-an untuk berbagai macam bentuk pengembangan produk seperti strategi dan metode pembelajaran, media dan bahan ajar. Dengan demikian, dapat membantu instruktur pelatihan dalam pengelolaan pelatihan dan pembelajaran (Branch \& Kopcha, 2014). Gambar 1 di bawah ini adalah gambar desain yang digunakan dalam penelitian ini:

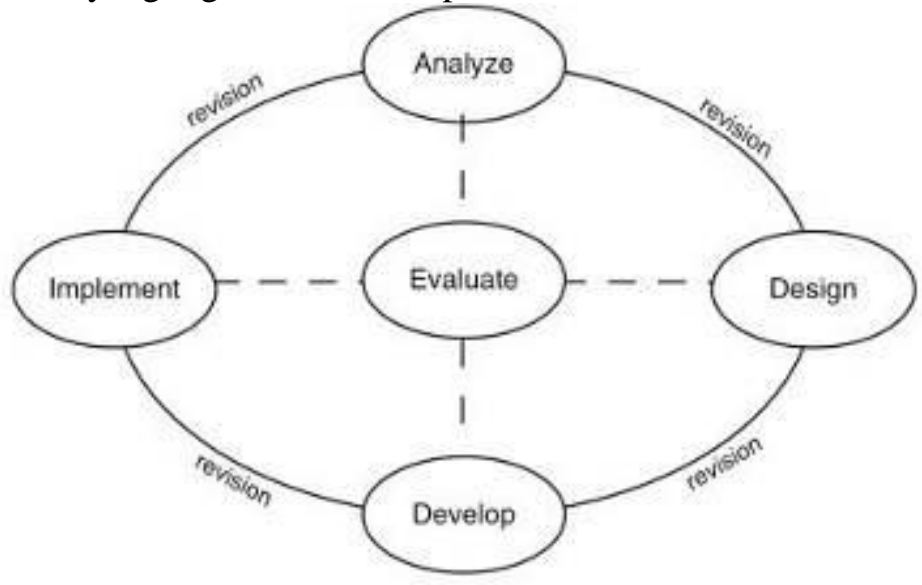

Gambar 1. The ADDIE Concept

Sumber: Branch, Robert, 2009,2.

Dengan bersumber pada desain pembelajaran ini, maka prosedur penelitian yang dilakukan adalah mengikuti langkah-langkah dalam bagan tersebut. Berikut adalah langkah-langkah yang dilakukan dalam penelitian ini.

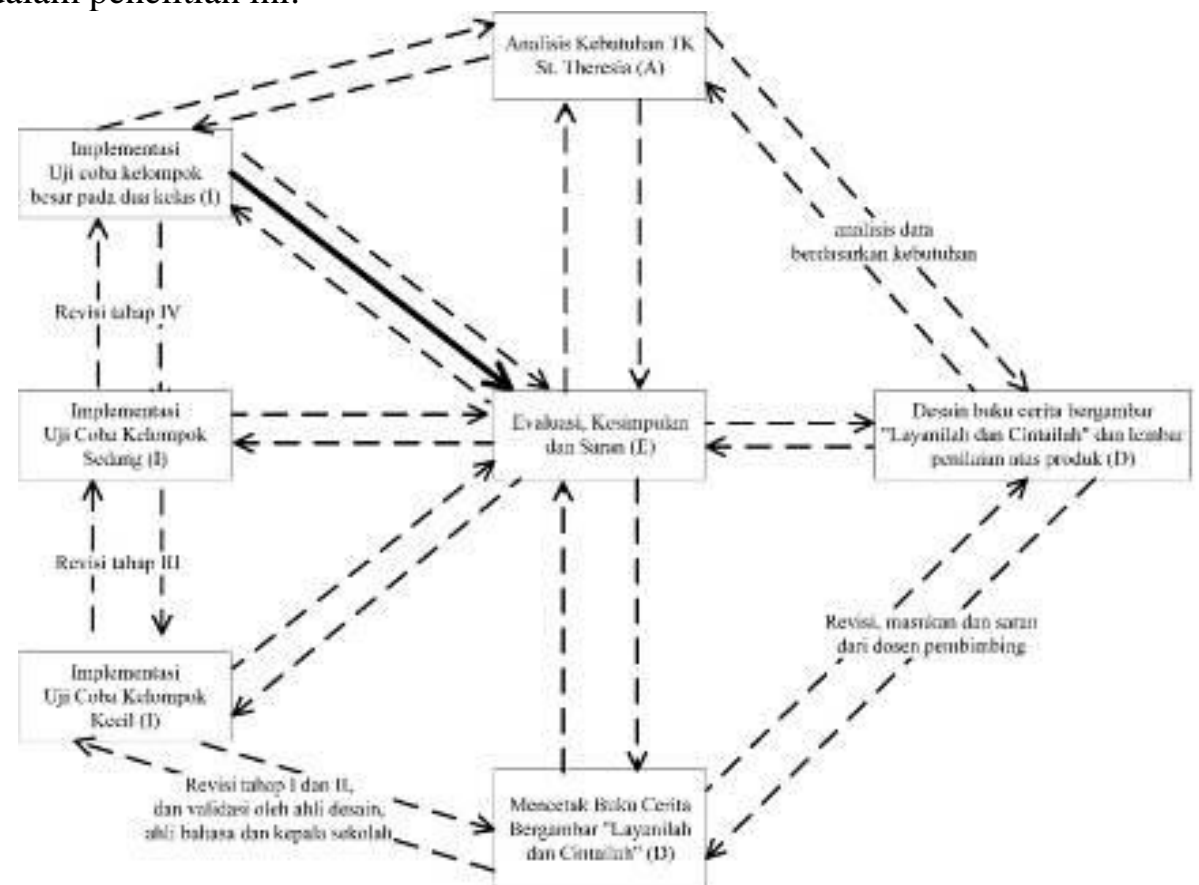

Bagan 1. Langkah-langkah Penelitian 
Penelitian ini dilakukan di sekolah Katolik yang terletak di Jakarta Pusat, pada bulan Juli 2018 sampai dengan April 2019. Untuk memperoleh data, peneliti mengobservasi dan wawancara. Observasi dilakukan saat guru kelas mengajar serta mengamati buku-buku yang dipakai di Taman Kanak-kanak (TK) ini untuk pendidikan karakter. Informan dalam wawancara dilakukan kepada guru kelas. Pada setiap tahapan pengembangan peneliti menggunakan instrumen lembar validasi yang berguna untuk merevisi tahap selanjutnya. Hasil analisis pengaruh dan kebermanfaatan dari buku cerita bergambar didapat dari uji coba yang dilakukan kepada dua kelas TK B dengan treatment yang berbeda.

\section{HASIL PENELITIAN DAN PEMBAHASAN}

\section{Proses Pengembangan Buku Cerita Bergambar}

Berdasarkan hasil wawancara kepada guru-guru dan hasil observasi yang dilakukan. Dihimpun informasi, bahwa guru mengalami kesulitan mencari bahan ajar terkait dengan penanaman nilai-nilai karakter sesuai dengan visi dan misi sekolah. Hal ini, karena belum ada buku panduan dan atau buku cerita yang benar-benar memuat materi pendidikan karakter, khusus buat anak usia dini, sesuai visi misi sekolah. Buku cerita yang tersedia di sekolah tersebut hanya memuat pendidikan karakter secara umum. Tidak mengerucut pada visi dan misi yang diusung oleh sekolah. Padahal sekolah hendak membentuk karakter anak sejak dini sesuai nilai servite et amate (layanilah dan cintailah). Dengan demikian analisis kebutuhan dari TK ini adalah buku cerita bergambar.

Tahap berikutnya adalah mendesain sebuah buku cerita bergambar yang sesuai dengan nilainilai servite et amate dengan ukuran A4 $(21 \mathrm{~cm}$ x 29,7 cm), menentukan tokoh, ide, dan alur cerita, menentukan jenis font yang akan dipakai, serta menyusun rubrik validasi yang digunakan untuk mengevaluasi produk buku cerita serta tes umpan balik yang diberikan kepada anak.

Setelah tahapan desain selesai, tahap berikutnya adalah mengembangkan buku cerita bergambar. Tahapan pengembangan ini terdiri dari langkah-langkah berikut ini:

\section{a) Mencetak buku}

Buku cetakan tahap pertama dicetak pada tanggal 18 September 2018. Buku dicetak sesuai ukuran yang diinginkan yaitu $21 \mathrm{~cm}$ x 29,7 cm. Dalam langkah ini penulis belum menentukan judul dan cover cerita. Total halaman pada cetakan pertama sebanyak 23 halaman. Gambar hasil cetak dan pewarnaan serta penggunaan huruf desain tahap pertama dapat dilihat pada Gambar 2 di bawah ini.

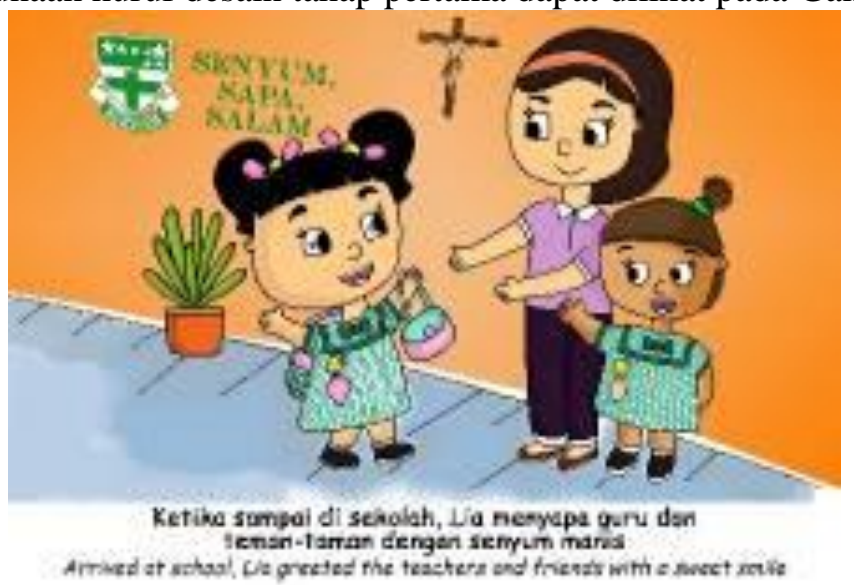

Gambar 2. Cetakan pertama buku cerita bergambar Sumber: Halim, 2019.

Dari gambar tersebut terlihat bahwa pada cetakan pertama rambut pada tokoh Lia masih kurang sempurna. Warna belum terlihat kontras dan serasi, dan penempatan tulisan masih kurang serasi. Pemberian nomor halaman pada buku cerita belum ada. Penulisan teks menggunakan font comic sans dan warna masih sama antara teks bahasa Indonesia dan teks bahasa Inggris. Hasil cetak pertama ini belum divalidasi dan di evaluasi oleh para ahli.

b) Validasi Tahap I-IV oleh Ahli Desain, Ahli Bahasa serta Ahli Isi/materi

Hasil buku yang sudah dicetak kemudian dievaluasi oleh para ahli, yakni ahli desain, ahli bahasa, dan ahli isi/ materi. Penilaian untuk evaluasi atas buku cerita bergambar dibuat dengan mengacu pada rubrik atas produk dan menggunakan skor 1-4. 
Dampak Pengembangan Buku Cerita Bergambar Untuk Anak Usia Dini

(Dellya Halim, Ashiong Parhehean Munthe)

Skor 1 = tidak baik. Skor 2 = kurang baik. Skor 3 = baik. Skor $4=$ sangat baik. Untuk menunjukkan kriteria kelayakan atas produk maka dibuat persentase berdasarkan interval. Persentase $0 \%-25 \%=$ tidak layak, $25,1 \%-50 \%=$ kurang layak, $50,1 \%-75 \%=$ layak, dan $75,1 \%-100 \%=$ sangat layak. Hasil persentase didapat dengan: Persentase skor $=\frac{\bar{x} \text { skor }}{4} \times 100 \%$. Tabel 1. - Tabel 3. adalah lembar evaluasi yang akan dinilai oleh para ahli.

Tabel 1. Lembar Validasi Desain untuk Ahli Desain

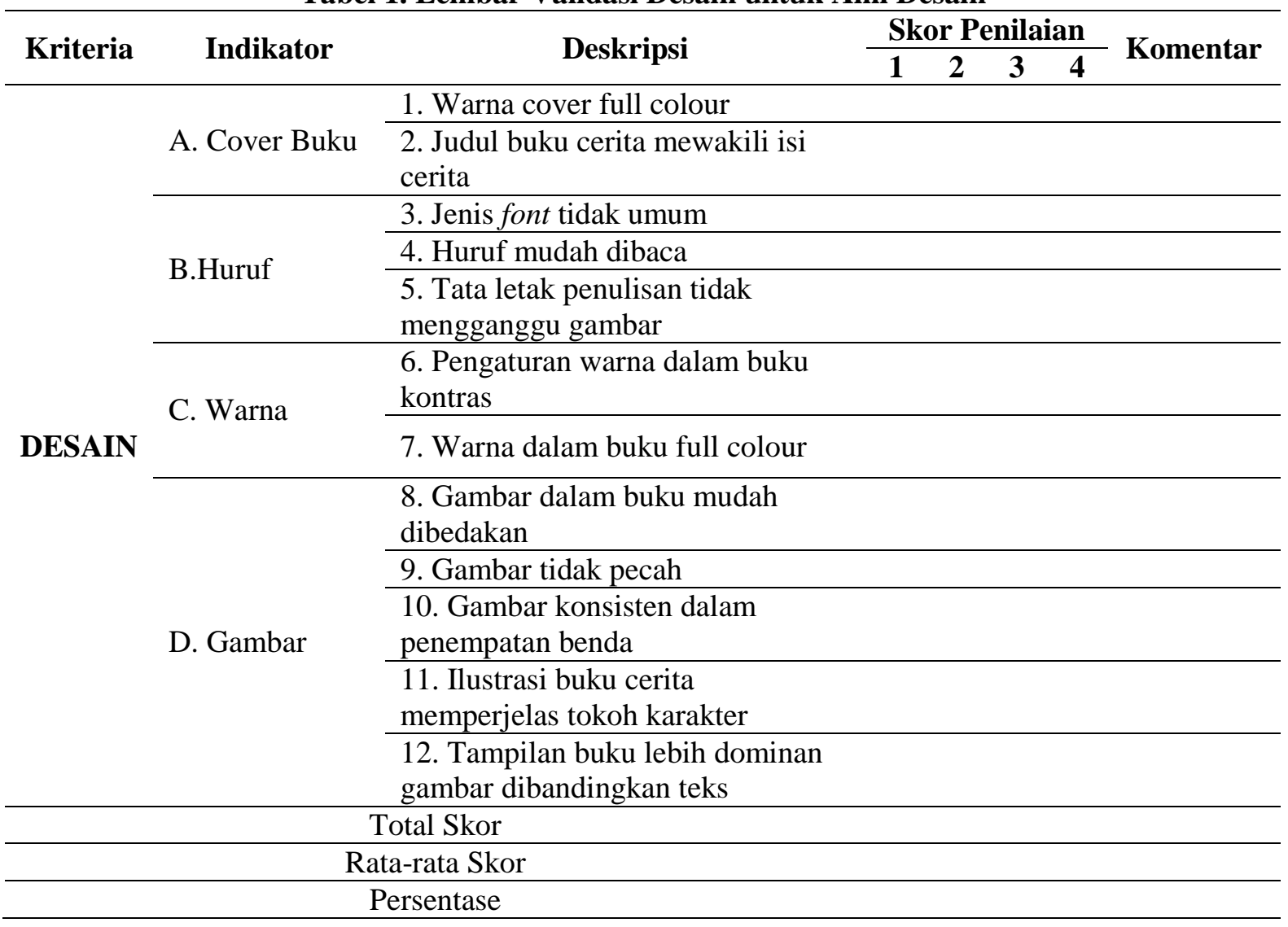

Tabel 2. Lembar Validasi Bahasa untuk Ahli Bahasa

\begin{tabular}{|c|c|c|c|c|c|}
\hline \multirow{2}{*}{ Kriteria } & \multirow{2}{*}{ Indikator } & \multirow{2}{*}{ Deskripsi } & \multicolumn{2}{|c|}{ Skor penilaian } & \multirow{2}{*}{ Komentar } \\
\hline & & & 12 & $\begin{array}{ll}3 & 4\end{array}$ & \\
\hline \multirow{9}{*}{ BAHASA } & $\begin{array}{l}\text { Gaya } \\
\text { Bahasa }\end{array}$ & $\begin{array}{l}\text { 1. Gaya bahasa menggunakan bahasa } \\
\text { sederhana sesuai untuk anak usia } \\
\text { dini }\end{array}$ & & & \\
\hline & $\begin{array}{l}\text { Ketepatan } \\
\text { Istilah }\end{array}$ & $\begin{array}{l}\text { 2. Istilah yang digunakan sesuai } \\
\text { dengan maknanya }\end{array}$ & & & \\
\hline & Huruf & $\begin{array}{l}\text { 3. Ukuran huruf pada tulisan bisa } \\
\text { dibaca dengan jelas }\end{array}$ & & & \\
\hline & Terjemahan & $\begin{array}{l}\text { 4. Terjemahan ke dalam bahasa } \\
\text { inggris menggunakan bahasa } \\
\text { sederhana serta jelas sesuai artinya }\end{array}$ & & & \\
\hline & $\begin{array}{l}\text { Ketepatan } \\
\text { ejaan }\end{array}$ & 5. Menggunakan PUEBI & & & \\
\hline & Tata Letak & $\begin{array}{l}\text { 6. Tata letak penulisan memudahkan } \\
\text { anak untuk membaca }\end{array}$ & & & \\
\hline & & Total Skor & & & \\
\hline & & ata-rata Skor & & & \\
\hline & & Persentase & & & \\
\hline
\end{tabular}


Tabel 3. Lembar Validasi atas Isi/ Materi untuk Ahli Isi/Materi

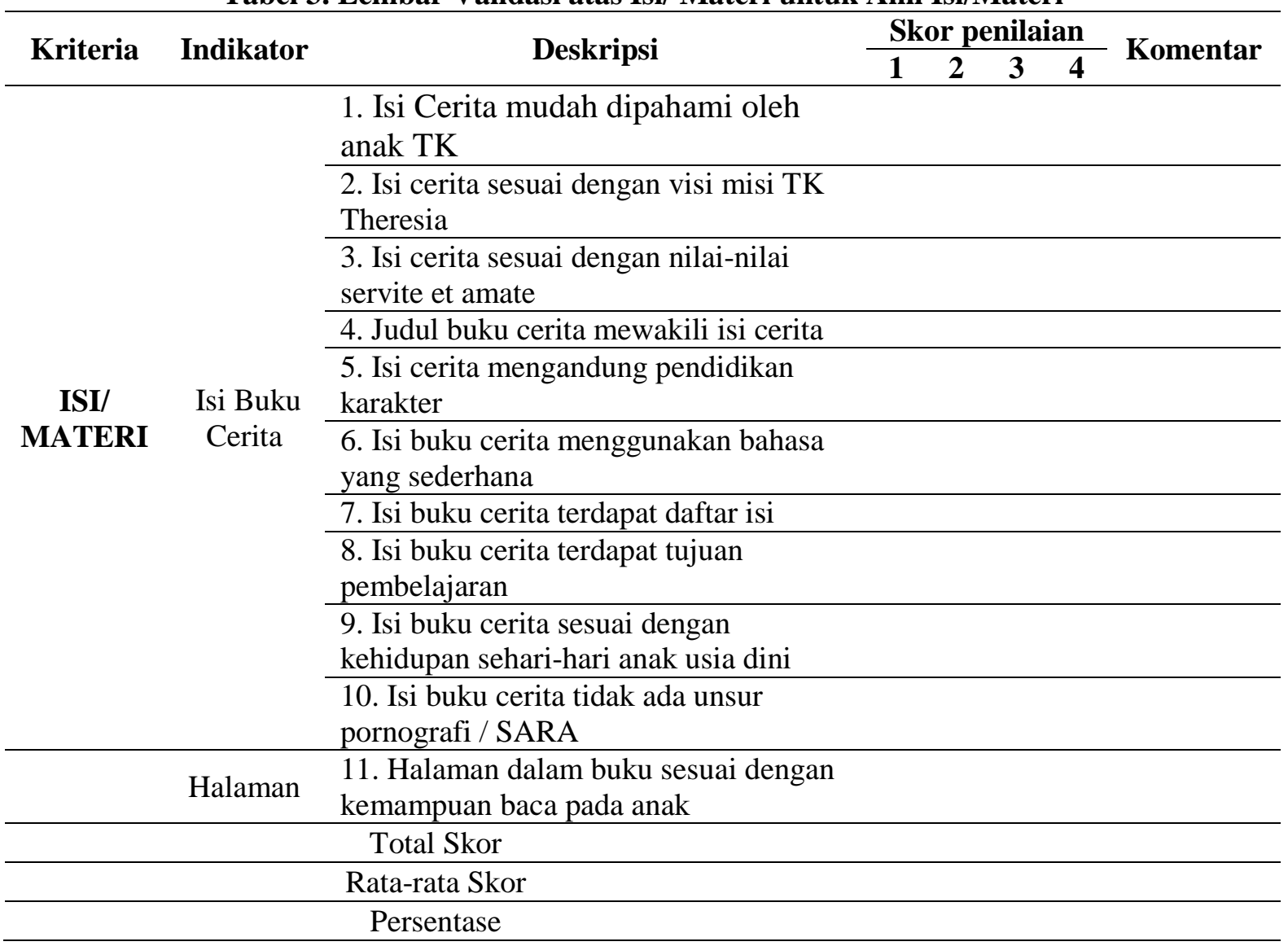

Hasil evaluasi yang didapat dari ahli desain, ahli bahasa dan ahli isi/ materi dalam bentuk skor dana persentase pada empat tahap terdapat dalam tabel 4 dan tabel 5 di bawah ini.

Tabel 4. Tabel Hasil Evaluasi Ahli dari Tahap I-IV dalam Bentuk Skor

\begin{tabular}{lccccc}
\hline \multicolumn{1}{c}{ Ahli } & Tahap I & Tahap II & Tahap III & Tahap IV & Dari Total Skor \\
\hline Desain & 22 & 39 & 46 & 48 & 48 \\
\hline Bahasa & 9 & 17 & 17 & 24 & 24 \\
\hline Isi/ Materi & 32 & 38 & 44 & 44 & 44 \\
\hline
\end{tabular}

Tabel 5. Tabel Hasil Evaluasi Ahli dari Tahap I-IV dalam Bentuk Persentase

\begin{tabular}{lccccc}
\hline \multicolumn{1}{c}{ Ahli } & Tahap I & Tahap II & Tahap III & Tahap IV & Dari Total Persen \\
\hline Desain & $45,0 \%$ & $81,0 \%$ & $95,0 \%$ & $100,0 \%$ & $100 \%$ \\
\hline Bahasa & $37,5 \%$ & $70,0 \%$ & $70,0 \%$ & $100,0 \%$ & $100 \%$ \\
\hline Isi/ Materi & $72,0 \%$ & $86,0 \%$ & $100,0 \%$ & $100,0 \%$ & $100 \%$ \\
\hline
\end{tabular}

Di bawah ini ada beberapa contoh gambar revisi desain yang telah dilakukan oleh peneliti dari proses tahap evaluasi I hingga tahap IV. Pada tampilan di bawah ini terdapat Gambar 3, Gambar 4, Gamabr 5, Gambar 6, Gambar 7, Gambar 8, Gambar 9, Gambar 10, Gambar 11, Gambar 12, dan Gambar 13 sebagai bagian dari pengembangan produk akhir dalam penelitian ini. Adapun gambargambarnya adalah sebagai berikut: 
Dampak Pengembangan Buku Cerita Bergambar Untuk Anak Usia Dini

(Dellya Halim, Ashiong Parhehean Munthe)

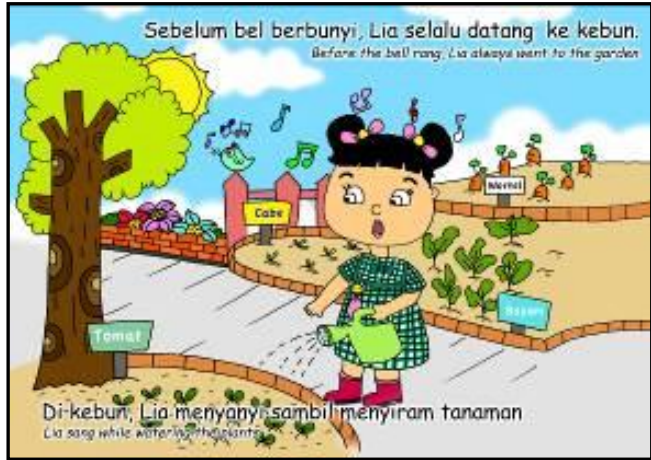

Gambar 3. Cetakan pertama halaman 3 Sumber: Halim, 2019.

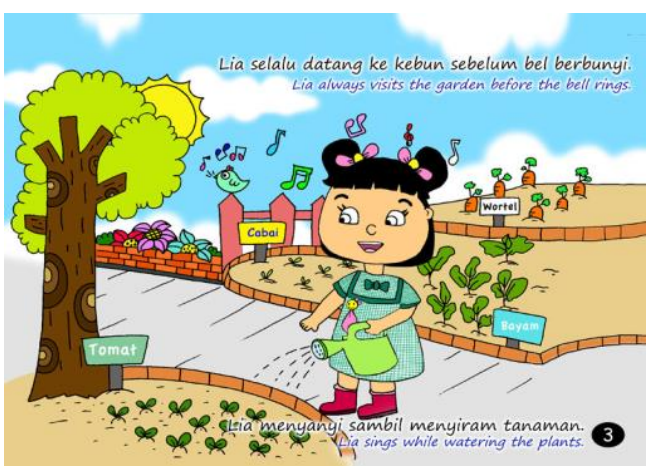

Gambar 5. Cetakan keempat halaman 3 Sumber: Halim, 2019.

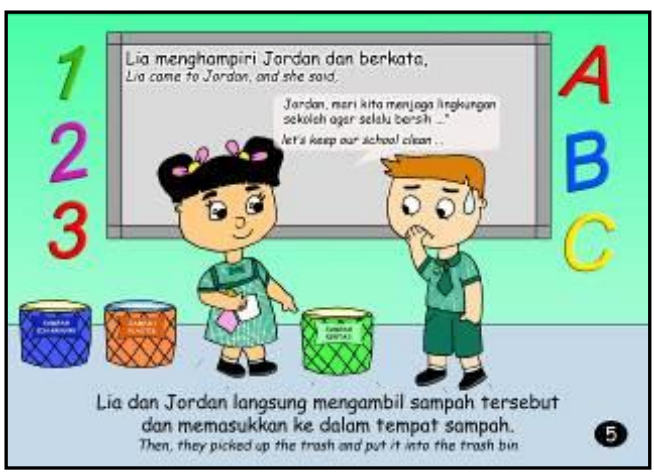

Gambar 7. Cetakan kedua halaman 5 Sumber: Halim, 2019.

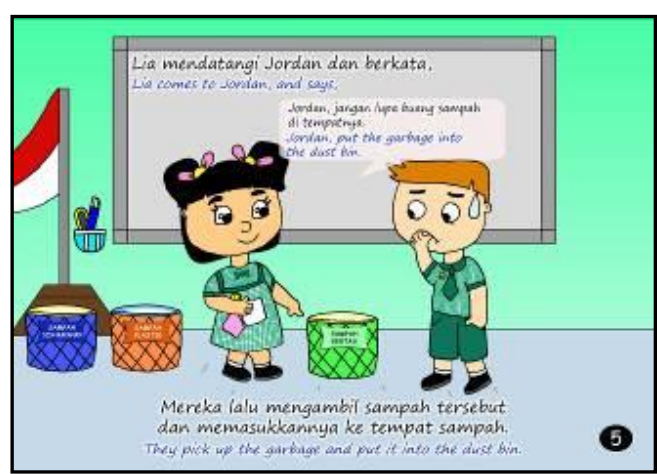

Gambar 9. Cetakan keempat halaman 5 Sumber: Halim, 2019.

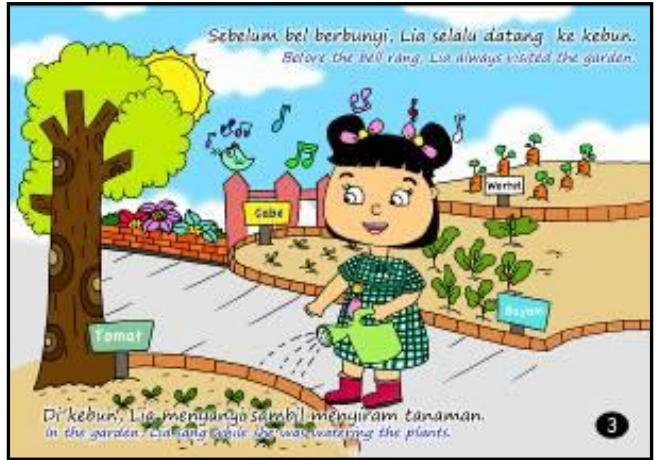

Gambar 4. Cetakan ketiga halaman 3 Sumber: Halim, 2019.

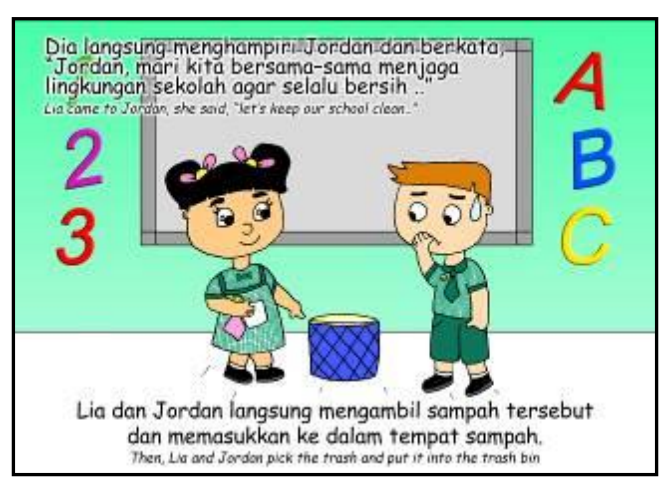

Gambar 6. Cetakan pertama halaman 5 Sumber: Halim, 2019

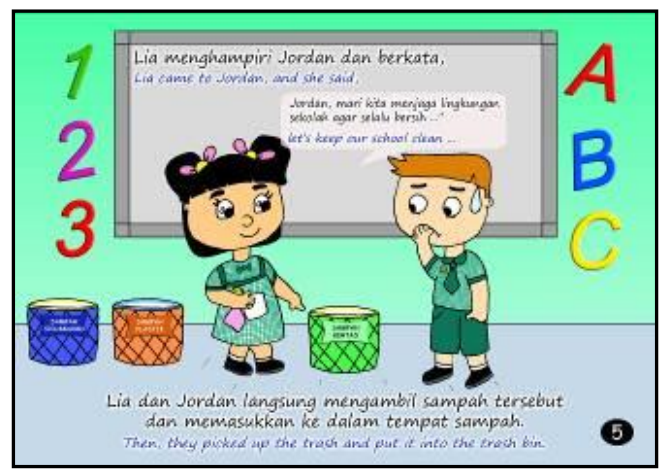

Gambar 8. Cetakan ketiga halaman 5 Sumber: Halim, 2019.

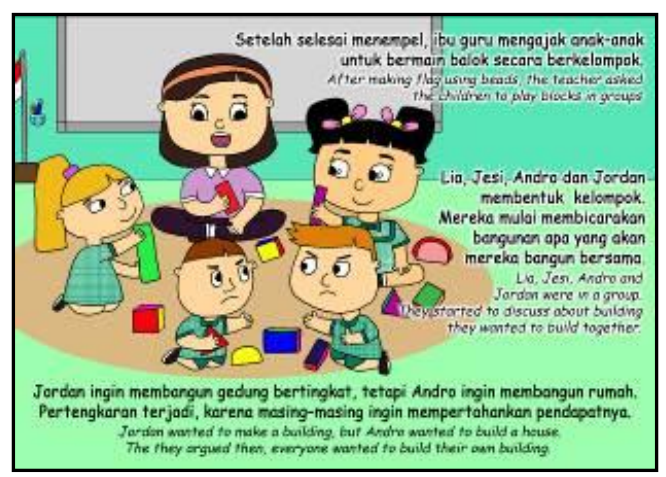

Gambar 10. Cetakan pertama halaman 15 Sumber: Halim, 2019. 


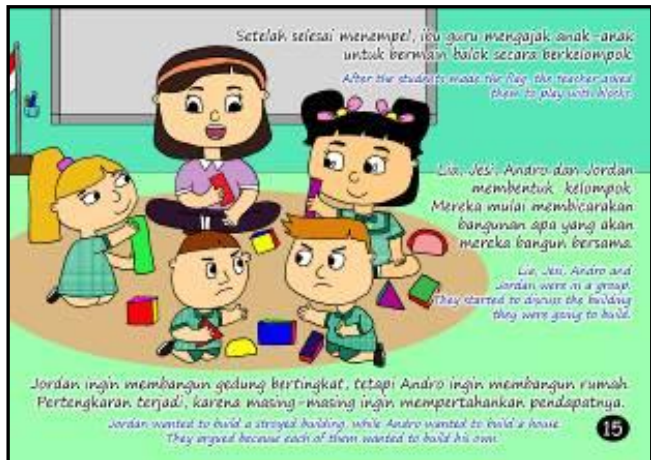

Gambar 11.Cetakan kedua halaman 15 Sumber: Halim, 2019.

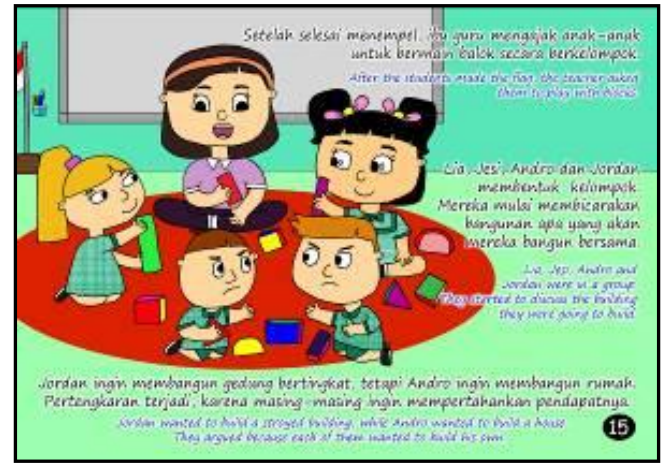

Gambar 12. Cetakan ketiga halaman 15 Sumber: Halim, 2019.

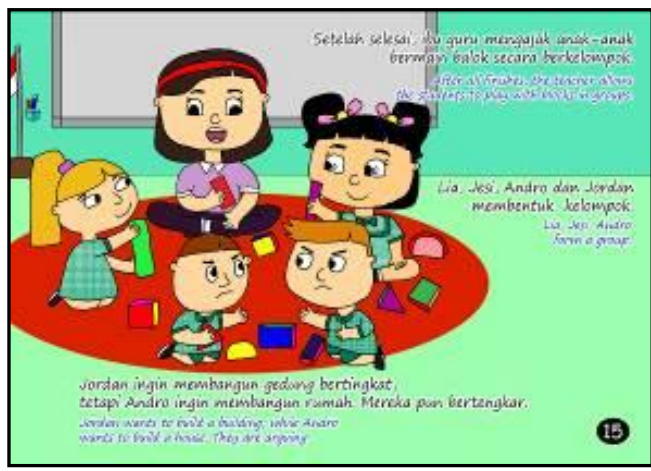

Gambar 13.Cetakan keempat halaman 15 Sumber: Halim, 2019.

Gambar 3 - gambar 13 merupakan proses revisi berdasarkan evaluasi yang didapat dari para ahli terhadap buku cerita bergambar dari tahap I-IV. Tahap pertama penilaian dari ahli desain mendapatkan skor 22 dengan rata-rata skor 1,8. Dan mendapatkan persentase sebesar $45 \%$ dengan kategori belum layak untuk diujicobakan. Tahap pertama saran dari ahli desain tentang buku cerita bergambar adalah tokoh utama anak perempuan yang bernama Lia, diberi rambut bagian belakang agar terlihat lebih seperti anak perempuan. Pewarnaan yang lebih kontras. Konsistensi background yang sama agar lebih diperhatikan. Tulisan dipersingkat agar tidak memenuhi gambar. Konsistensi pewarnaan pada subyek gambar (misalnya bando yang dipakai guru dan sapu tangan yang dipakai Lia) agar diberi warna yang sama. Tahap pertama penilaian dari ahli bahasa mendapatkan skor 9 dengan rata-rata skor 1,5. Dan mendapatkan persentase sebesar 37,5\% dengan kategori belum layak untuk diujicobakan. Saran oleh ahli bahasa adalah setiap halaman menggunakan tanda baca titik pada akhir kalimat, serta penggunaan bahasa Inggris yang sederhana untuk anak TK yakni menggunakan kalimat present tense yang mudah dimengerti oleh anak. Bahasa terjemahan ke dalam bahasa Inggris yang digunakan menggunakan kalimat past tense dinilai terlalu sulit untuk anak TK, karena anak baru mengenal tata bahasa yang sederhana dalam bentuk present tense. Tahap pertama penilaian dari ahli isi/materi mendapatkan skor 32 dengan rata-rata skor 2,9. Dan mendapatkan persentase sebesar 72\% dengan kategori sudah layak dengan revisi untuk diujicobakan. Dari ahli isi/materi, saran yang diberikan adalah melengkapi buku cerita dengan cover, judul cerita dan tujuan pembelajaran untuk kemudahan guru yang menggunakan buku ini. di halaman depan ditambahkan pengantar yang menjelaskan tujuan pembelajaran dan isi buku cerita. Daftar Isi yang menjelaskan nilai-nilai dari buku cerita. Penggunaan font yang menarik agar anak minat untuk membaca. Pemberian warna yang berbeda pada teks bahasa inggris dan bahasa Indonesia. Tipe huruf dalam kalimat bisa dirubah, dari comic sans menjadi huruf yang lebih menarik. Judul cerita diganti dari "Amsalia" menjadi "Layanilah dan Cintailah". Pada tahap pertama ini buku cerita belum digunakan untuk uji coba karena masih banyak yang perlu diperbaiki dari segi desain dan bahasa.

Tahap kedua penilaian dari ahli desain meningkat. Skor yang didapat pada tahap kedua dari ahli desain adalah 39 dengan rata-rata skor 3,2. Dan mendapatkan persentase sebesar $81 \%$ dengan kategori sudah sangat layak untuk diujicobakan. Saran dari ahli desain tentang buku cerita bergambar 
adalah lain konsisten penempatan benda dalam kelas, misalnya di sebelah papan tulis ada tempat spidol whiteboard dan tiang bendera merah putih. Konsisten pemberian warna pada bando yang dipakai guru pada setiap halaman. Konsisten pewarnaan baju tokoh Lia dan tokoh yang lain. Pengaturan warna kulit dan karpet yang mirip. Dialog-dialog jangan terlalu banyak pada halaman-halaman tertentu. Penempatan posisi halaman yang salah pada semua halaman. Tulisan pada kata pengantar sebaiknya tidak diberi glow/ bayangan putih. Tahap kedua penilaian dari ahli bahasa mendapatkan skor 17 dengan rata-rata skor 2,8. Dan mendapatkan persentase sebesar 70\% dengan kategori sudah layak untuk diujicobakan. Saran oleh ahli bahasa adalah ahli bahasa menyimpulkan bahwa penggunaan bahasa dalam buku cerita ini masih ada beberapa bagian yang perlu direvisi. Saran-saran yang diberikan oleh ahli bahasa untuk revisi pada tahap kedua ini adalah huruf dalam kata pengantar sebaiknya hitam saja tanpa effect glow. Konsistensi penggunaan font pada sinopsis cerita di bagian depan buku. Penggunaan pola kalimat yang benar agar diperhatikan pada setiap halaman. Penggunaan tanda baca koma yang tepat pada setiap kalimat. Tulisan dalam buku jangan terlalu panjang. Tahap kedua penilaian dari ahli isi/materi mendapatkan skor 38 dengan rata-rata skor 3,4. Dan mendapatkan persentase sebesar $86 \%$ dengan kategori sudah sangat layak dengan revisi untuk diujicobakan. Dari ahli isi/materi, saran yang diberikan adalah memperhatikan alur cerita agar tidak terputus, memperhatikan penulisan kalimat pada halaman tertentu, serta penggunaan tanda baca pada halaman yang benar. Saran-saran lain dari pembimbing adalah seputar judul Layanilah dan Cintailah yang merupakan akronim dari kata Servite et Amate. Pada bagian kata pengantar, dijelaskan analisis kebutuhan yang terdapat di bab I, serta menjelaskan kompetensi dasar yang diturunkan menjadi indikator serta tujuan pembelajaran yang ingin dicapai lewat buku cerita ini. Pada halaman akhir, di buat kesimpulan satu kalimat yang menggambarkan buku cerita tersebut. Peneliti sudah melakukan uji coba pada kelompok kecil ditahap ini.

Tahap ketiga penilaian dari ahli desain semakin meningkat. Skor yang didapat pada tahap ketiga dari ahli desain adalah 46 dengan rata-rata skor 3,8. Dan mendapatkan persentase sebesar 95\% dengan kategori sudah sangat layak untuk diujicobakan. Saran dari ahli desain tentang buku cerita bergambar adalah konsisten penempatan benda: menghapus tempat sampah pada halaman 4 dan menghapus angka dan huruf di dinding pada halaman 5. Pemberian warna pada bando guru harus sama pada halaman 13,15. Penambahan gambar pintu pada halaman 9. Tahap ketiga penilaian dari ahli bahasa mendapatkan skor 17 dengan rata-rata skor 2,8. Dan mendapatkan persentase sebesar 70\% dengan kategori sudah layak untuk diujicobakan. Saran oleh ahli bahasa adalah penggunaan pola kalimat yang sesuai agar diperhatikan pada halaman 1, 2, 3. Merevisi kata cabe, menjadi cabai. Penggunaan teks bahasa Inggris yang lebih sederhana untuk anak-anak. Penambahan gambar pintu pada halaman 9. Tahap ketiga penilaian dari ahli isi/materi mendapatkan skor 44 dengan rata-rata skor 4 . Dan mendapatkan persentase sebesar 100\% dengan kategori sudah sangat layak untuk diujicobakan. Dari ahli isi/materi, saran yang diberikan adalah memperhatikan penulisan kalimat pada halaman 14, 15, 16, dan 19. Memberikan pertanyaan penuntun pada akhir cerita. Selain itu, komentar / saran juga diperoleh dari pembimbing, pada revisi tahap ketiga ini antara lain kata pengantar agar bisa diberi jarak sehingga lebih renggang dan tidak terlalu rapat. Pada tahap ini, peneliti sudah melakukan ujicoba pada kelompok sedang.

Tahap keempat penilaian dari ahli desain semakin meningkat. Skor yang didapat pada tahap ketiga dari ahli desain adalah 48 dengan rata-rata skor 4. Dan mendapatkan persentase sebesar $100 \%$ dengan kategori sudah sangat layak untuk diujicobakan. Saran dari ahli desain tentang buku cerita bergambar yaitu konsisten pewarnaan bando pada bu guru di halaman 13 dan 15. Tahap keempat penilaian dari ahli bahasa mendapatkan skor 24 dengan rata-rata skor 4. Dan mendapatkan persentase sebesar 100\% dengan kategori sudah sangat layak untuk diujicobakan. Saran oleh ahli bahasa adalah penggunaan pola kalimat yang sesuai agar diperhatikan pada halaman 1, 2, 3. Merevisi kata cabe, menjadi cabai. Penggunaan teks bahasa Inggris yang lebih sederhana untuk anak-anak. Penambahan gambar pintu pada halaman 9. Tahap keempat penilaian dari ahli isi/materi mendapatkan skor 44 dengan rata-rata skor 4. Dan mendapatkan persentase sebesar 100\% dengan kategori sudah sangat layak untuk diujicobakan. Dari ahli isi/materi, saran yang diberikan adalah penulisan compassionate pada bagian pengantar. Penempatan teks terima kasih dipindahkan ke bawah. Sinopsis awal cerita dibuat lebih menarik agar anak ingin membaca lebih lanjut. Kalimat pada halaman 17 diperbaiki “......menurut”. menjadi “......berdiskusi”. Pada halaman 24 tambahkan narasi cerita agar tidak terputus. Saran-saran yang juga diperoleh dari dosen pembimbing untuk revisi tahap keempat ini adalah gambar pada 
lambang toilet sebaiknya memakai gambar yang umum. Memasukkan pertanyaan yang menunjang tujuan pembelajaran di belakang buku cerita. Setelah revisi tahap empat ini kemudian diujicobakan kepada 2 kelas TK B dengan treatment yang berbeda, yakni kelas B2 tanpa menggunakan buku cerita bergambar dan kelas B3 dengan menggunakan buku cerita bergambar.

\section{Analisis dan Implementasi Buku Cerita Bergambar}

Tahap implementasi pada kelompok kecil dilakukan pada tanggal 22 Oktober 2018 kepada lima orang anak yang dipilih secara acak dari TK B2 dan B3. Uji coba kelompok sedang dilakukan pada tanggal 7 Desember 2018 pada ke 13 anak B1. Dan uji coba kelompok besar pada dua kelas dilakukan pada tanggal 18 Desember 2018. Uji coba dilakukan dengan cara penggunaan buku cerita bergambar di kelas oleh guru. Selama penggunaan produk peneliti melakukan observasi terhadap penggunaan media tersebut. Guru TK yang berpengalaman juga diwawancara untuk diminta tanggapan, saran, dan komentarnya mengenai buku cerita yang dikembangkan.

Pada uji coba kelompok kecil, umpan balik terhadap produk dan materi dari anak adalah gambar telihat jelas oleh anak. Warna dalam buku cerita menarik dan bagus. Menurut anak-anak, isi ceritanya bagus. Gambar sesuai dengan isi ceritanya. Hal ini dibuktikan dengan anak mengerti dan paham dengan jelas tokoh-tokoh yang ada dalam buku cerita. Anak mengerti alur ceritanya dan bisa menjawab pertanyaan guru dengan benar. Umpan Balik dari guru terhadap produk dan materi yaitu gambar terlihat jelas. Komposisi warna dalam buku cerita menarik. Tulisan terlihat jelas. Karakter tokoh sesuai dengan isi cerita. Anak-anak terlihat tertarik dengan buku cerita ini. Buku cerita ini dapat dipahami dengan baik oleh anak-anak. Buku cerita ini sesuai dengan nilai-nilai karakter servite et amate. Berdasarkan nilai posttest yang diperoleh pada kelompok kecil dengan jumlah lima orang dilakukan uji coba, maka hasil nilai rata-rata terhadap soal adalah baik. Pada saat observasi, kelima anak terlihat tertarik dan antusias mengikuti dan mendengarkan cerita dengan menggunakan buku cerita bergambar sampai selesai. Anakanak dapat menjawab pertanyaan dengan benar. Mereka juga dapat mengerjakan soal pertanyaan yang berkaitan dengan gambar tokoh dalam cerita serta contoh-contoh nilai servite et amate dengan benar. Kesan dari guru yang menjadi observer adalah anak-anak terlihat antusias. Buku ceritanya sangat menarik dan membantu anak-anak untuk memahami isi cerita. Sehingga ketika akhir kegiatan, dilakukan tanya jawab anak-anak dapat menjawab pertanyaan dengan benar.

Pada uji coba kelompok sedang, umpan balik terhadap produk dan materi bahwa gambar telihat jelas oleh anak. Warna dalam buku cerita menarik dan bagus. Menurut anak-anak, isi ceritanya bagus. Gambar sesuai dengan isi ceritanya. Hal ini dibuktikan dengan anak mengerti dan paham dengan jelas tokoh-tokoh yang ada dalam buku cerita. Anak mengerti alur ceritanya dan bisa menjawab pertanyaan guru dengan benar. Umpan balik dari guru terhadap produk dan materi adalah gambar terlihat jelas. Komposisi warna dalam buku cerita menarik. Tulisan terlihat jelas. Karakter tokoh sesuai dengan isi cerita. Anak-anak terlihat tertarik dengan buku cerita ini. Buku cerita ini dapat dipahami dengan baik oleh anak-anak. Buku cerita ini sesuai dengan nilai-nilai karakter servite et amate. Berdasarkan nilai posttest yang diperoleh pada kelompok sedang dengan jumlah 13 orang dilakukan uji coba, maka hasil nilai rata-rata adalah baik.

Pada uji coba kelompok besar, dilakukan pada 2 kelas yang berbeda (masing-masing berjumlah 22 anak) dengan treatment yang berbeda pula. Kelas yang satu diceritakan tanpa menggunakan buku cerita bergambar (kelas B2), dan kelas yang lainnya diceritakan dengan menggunakan buku cerita bergambar (kelas B3). Nilai Posttest pada kelompok besar tanpa produk buku cerita bergambar diambil setelah siswa mendapatkan pembelajaran dengan metode bercerita tanpa menggunakan produk. Uji coba pada kelompok besar tanpa produk (B2) dilakukan pada tanggal 18 Desember 2018. Instrumen yang digunakan untuk mengumpulkan data adalah dengan menggunakan tes Benar-Salah dan menyebutkan bentuk tindakan yang benar. Jumlah siswa yang diobservasi dengan menggunakan tes adalah 22 orang. Skoring penilaian yang dilakukan dalam uji coba kelas B2 tanpa produk ini dengan menggunakan angka nilai 0-10 (telah dikonversi dengan dikalikan 10). Ada dua soal yang mendapatkan nilai jawaban paling tinggi, yaitu soal nomor satu tentang pemahaman tokoh utama dan karakter yang dimiliki. Soal yang kedua adalah tentang pemahaman nilai tentang nilai core values serviam yaitu sikap menghargai lingkungan. Kedua nilai dari kedua soal ini mendapatkan nilai yang sama, yakni 9,5. Soal yang mendapatkan jawaban terendah adalah soal nomor 4 yaitu dengan nilai 4,1 . Pada saat observasi, hanya lima anak yang bisa menjawab pertanyaan dengan benar secara lisan. Empat anak tidak bisa menjawab pertanyaan dengan benar. Yang lainnya menjawab dengan ragu-ragu dan tidak tertarik dan 
tidak fokus saat mengikuti kegiatan di kelas. Anak-anak tidak dapat mengerjakan soal pertanyaan yang berkaitan dengan gambar tokoh dalam cerita. Kondisi kelas cenderung lebih ramai dan ribut. Kesan dari guru yang menjadi observer adalah anak-anak terlihat kurang fokus dan konsentrasi. Mereka kurang mendengarkan cerita, dan cenderung ribut sendiri. Anak-anak juga kurang antusias.

Uji coba dengan menggunakan produk dilakukan pada kelas B3 pada tangal yang sama. Nilai Posttest pada kelompok besar dengan menggunakan produk buku cerita bergambar diambil setelah siswa mendapatkan pembelajaran dengan metode bercerita dan menggunakan media berupa buku cerita bergambar. Instrumen yang digunakan untuk mengumpulkan data sama dengan instrumen yang digunakan pada kelompok besar tanpa produk yakni menggunakan tes Benar-Salah dan menyebutkan contoh bentuk tindakan yang benar. Jumlah siswa yang diobservasi dengan menggunakan tes adalah 22 orang. Skoring penilaian yang dilakukan dalam uji coba kelas B3 dengan produk ini menggunakan angka nilai 0-10 (telah dikonversi dengan dikalikan 10). Nilai postest terlihat bahwa ketujuh soal mendapatkan nilai mean yang tinggi, yakni 10. Pada saat observasi, anak-anak terlihat tertarik dan antusias mengikuti dan mendengarkan cerita dengan menggunakan buku cerita bergambar sampai selesai. Anak-anak dapat menjawab pertanyaan dengan benar. Mereka juga dapat mengerjakan soal pertanyaan yang berkaitan dengan gambar tokoh dalam cerita serta contoh-contoh nilai servite et amate dengan benar. Kondisi kelas terkesan aktif dan menyenangkan. Kesan dari guru yang menjadi observer adalah anak-anak terlihat antusias. Buku ceritanya sangat menarik dan membantu anak-anak untuk memahami isi cerita. Sehingga ketika akhir kegiatan ini, dilakukan tanya jawab anak-anak dapat menjawab pertanyaan dengan benar.

Gambar 14. di bawah ini adalah grafik nilai perbandingan antara kelas tanpa produk (B2) dan menggunakan produk (B3).

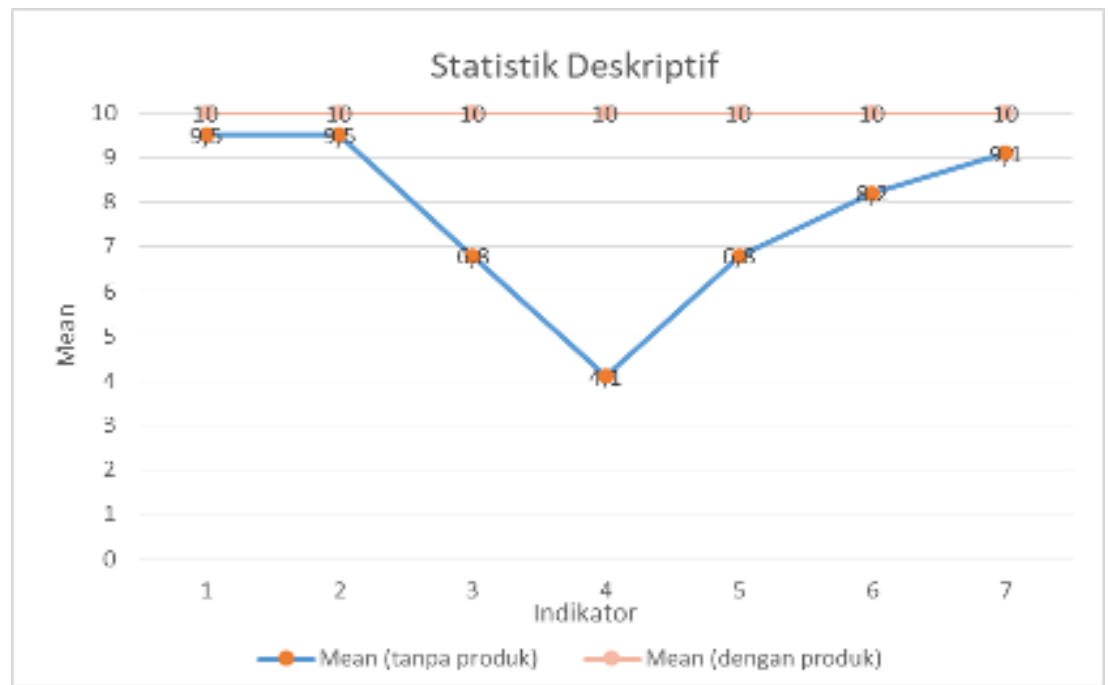

Gambar 14. Grafik Perbandingan Posttest Kelas B2 dan B3

Dari grafik di atas nampak perbedaan hasil yang dicapai antara kelas tanpa produk dengan kelas yang menggunakan produk. Pada kelas yang menggunakan produk semua item soal mendapatkan hasil yang baik. Pada kelas yang tanpa produk, terlihat hasil anak kurang maksimal dalam menjawab pertanyaan soal yang diberikan. Dengan demikian terlihat bahwa buku cerita bergambar yang dikembangkan memiliki dampak terhadap pemahaman anak.

Perbedaan capaian yang signifikan terlihat pada soal nomor 3, 4 dan 5. Nilai selisih terbesar terdapat pada soal nomor 4 yaitu soal berkaitan dengan contoh sikap kemandirian. Nilai selisih pada soal nomor 4 ini adalah 5,9. Pada soal nomor 4 ini, perbedaan capaian cukup signifikan. Hal ini menunjukkan bahwa tanpa buku cerita anak-anak B2 masih belum mampu memahami dan menyebutkan contoh sikap mandiri seperti yang telah diceritakan. Sedangkan pada kelas B3 semua anak dapat menyebutkan dengan benar. Nilai selisih dari kelas B2 dan B3 untuk soal nomor 3 adalah 3,2 dengan kategori pencapaian rendah. Hal ini menunjukkan bahwa tanpa buku cerita anak-anak tidak bisa memahami dan menyebutkan contoh sikap kepedulian. Sebaliknya pada anak kelas B3 dimana kelas yang menggunakan produk anak dapat menjawab dengan benar. Nilai selisih pada soal nomor 5 ini 
adalah 3,2. Hal ini menunjukkan bahwa tanpa buku cerita anak-anak B2 kurang mampu memahami dan menyebutkan contoh sikap yang berkaitan dengan kesopanan dengan benar. Pada kelas B3 mereka dapat menjawab pertanyaan soal nomor 5 ini dengan benar. Dari selisih mean kedua kelas tersebut menunjukkan bahwa buku cerita bergambar yang dikembangkan ini memiliki pengaruh dan kebermanfaatan untuk digunakan dalam pembelajaran servite et amate di sekolah tersebut.

Hasil temuan penelitian ini sejalan atau relevan dengan yang dikemukakan oleh Nomeli dan Manu (2018) bahwa bahwa media dan alat peraga yang dikembangkan oleh guru dapat meningkatkan kemampuan pemahaman konsep pada siswa. Alsamadani (2017) pun mengungkapkan dalam penelitiannya bahwa buku cerita bergambar yang diceritakan membantu keterampilan mendengar dan pengucapan siswa serta membantu siswa dalam mengurutkan peristiwa dan menceritakan kembali seluruh isi cerita. Hal ini dibuktikan dengan hasil analisis kelas yang diceritakan dengan menggunakan buku cerita bergambar mengungguli kelas yang diceritakan tanpa buku cerita. Beberapa penelitian sebelumnya sejalan dengan penelitian ini bahwa buku cerita bergambar memiliki dampak positif dan kebermanfaatan terhadap perkembangan siswa dalam pembelajaran.

\section{SIMPULAN DAN SARAN}

Berdasarkan hasil penelitian dan pengembangan buku cerita bergambar Layanilah dan Cintailah, maka dapat disimpulkan: 1). Pengembangan Buku Cerita Bergambar yang berisi nilai-nilai karakter dasar pendidikan ursulin dengan judul "Layanilah dan Cintailah" dikembangkan dengan cara menganalisis kebutuhan. Pada saat mengobservasi perpustakaan dan saat mewawancarai Kepala Sekolah dan guru-guru TK disimpulkan bahwa belum adanya buku cerita yang sesuai dengan nilainilai servite et amate, buku cerita yang digunakan sejauh ini hanya mencakup sebagian kecil nilai servite et amate, sehingga kesulitan untuk membantu anak-anak dalam memahami contoh-contoh tindakan yang sesuai dengan nilai-nilai servite et amate. 2). Pengembangan Buku Cerita Bergambar dilaksanakan melalui langkah-langkah tahapan model ADDIE sehingga menghasilkan produk Buku Cerita Bergambar. 3). Buku Cerita Bergambar "Layanilah dan Cintailah" dikembangkan dengan melalui tahapan-tahapan pengembangan, salah satunya tahap validasi oleh para ahli yakni dosen pembimbing, kepala sekolah, ahli bahasa, ahli desain, dan editor buku cerita anak. Hasil validasi terakhir oleh ahli desain mendapatkan persentase $100 \%$ dengan kategori "sangat layak". Hasil validasi terakhir oleh ahli bahasa mendapatkan persentase 100\% dengan kategori "sangat layak". Hasil validasi terakhir oleh ahli isi/ materi mendapatkan persentase $100 \%$ dengan kategori "sangat layak". 4). Uji coba dengan menggunakan buku cerita dilakukan pertama kali pada kelima anak TK B1 dan mendapatkan hasil ratarata sangat baik. Uji coba yang kedua dilakukan pada 13 anak TK B1 serta mendapatkan hasil baik. Uji coba yang terakhir dilakukan pada 2 kelas TK B2 dan B3, Kelas B2 diujicobakan tanpa menggunakan buku cerita dan kelas B3 dengan menggunakan buku cerita. Hasil Uji coba pada kelompok besar dengan menggunakan produk juga menunjukkan pengaruh dan kebermanfaatan buku cerita bergambar tersebut dalam pembelajaran servite et amate. Hal ini dibuktikan dengan nilai-nilai yang diperoleh dari posttest yang diberikan. Anak TK B3 bisa menjawab dengan benar pertanyaan-pertanyaan yang diberikan seputar isi/ materi pada buku cerita. Sedangkan pada kelas B2 anak-anak kurang maksimal dan mengalami kebingungan saat menjawab pertanyaan. Anak kelas B2 tidak dapat menjawab pertanyaan pada nomor 3,4 dan 5 yakni yang berhubungan dengan contoh tindakan sikap kepedulian, kemandirian dan kesopanan. 5). Buku Cerita Bergambar Layanilah dan Cintailah ini memiliki kebermanfaatan bagi anak TK. Hal ini dibuktikan dengan total nilai selisih dari rata-rata mean yang didapat dari kelas B2 yaitu empat soal yang mendapatkan nilai mean paling tinggi. Tiga soal lainnya mendapatkan nilai mean yang rendah. Sedangkan pada kelas B3 yaitu ketujuh soal mendapatkan nilai 10 atau dalam arti jawaban benar semua. Hal ini menunjukkan bahwa buku cerita bergambar yang dikembangkan memiliki kebermanfaatan bagi anak TK. Perbedaan capaian yang signifikan terlihat pada jawaban 4 yakni dengan nilai selisih 5,9, serta nomor 3 dan 5 yakni dengan nilai selisih 3,2. Dengan demikian pengembangan buku cerita bergambar memberikan dampak yang positif bagi pemahaman anak usia dini khususnya dalam hal mengetahui contoh-contoh tindakan yang sesuai dengan nilai-nilai servite et amate.

Berdasarkan hasil penelitian ini, bahwa pengembangan buku cerita bergambar memiliki kebermanfaatan untuk anak usia dini. Ada beberapa hal yang bisa disarankan terkait pengembangan buku cerita bergambar tersebut, yaitu: 1). Alur, tokoh dan isi cerita yang disusun harus relevan bagi anak usia dini. 2) Penggunaan bahasa dan pemilihan diksi dalam cerita bergambar harus sesuai dengan 
Dampak Pengembangan Buku Cerita Bergambar Untuk Anak Usia Dini

(Dellya Halim, Ashiong Parhehean Munthe)

pertumbuhan kognitif anak usia dini. 3) Saat mengembangkan buku cerita bergambar, pengembang harus memperhatikan komposisi warna agar menarik dan ilustrasi mendorong imajinasi anak.

\section{DAFTAR PUSTAKA}

Alsamadani. 2017. The Effect of Talking Story Books on Saudi Young EFL Learners' Reading Comprehension. English Language Teaching; Vol. 10, (No.5)204-213.

Branch, Robert. 2009. Instructional Design: The ADDIE Approach. Department of Educational Psychology and Instructional Technology. USA: Springer Sciencep Business Media, LLC.

Branch, R. M., \& Kopcha, T. J. 2014. Instructional design models. In Handbook of research on educational communications and technology (pp. 77-87). Springer New York.

Borg, W.R., Gall, M.D., and Gall, Joyce. 2015. Applying Educational Research: How to Read, Do, and Use Research to Solve Problems of Practise. Pearson Education.

Berk, Laura E. 2012. Development trough the lifespan. Yogyakarta: Pustaka Pelajar.

Crowther, J. R. 1995. Theory and Practice. 42. New Jersey : Humana Press.

Evans, M. A., \& Saint-Aubin, J. 2005. What children are looking at during shared storybook reading: Evidence from eye movement monitoring. Psychological Science, 16(11)913-920.

Faizah, Umi. 2009. "Keefektifan Cerita Bergambar untuk Pendidikan Nilai dan Keterampilan Berbahasa Dalam Pembelajaran Bahasa Indonesia". Jurnal Cakrawala Pendidikan, Th. XXVIII, No. 3. (Online).

Hartati, S. 2005. Perkembangan belajar pada anak. Jakarta: Depdiknas.

Halim, Dellya. 2019. Layanilah dan Cintailah. Jakarta: Santa Theresia.

Hsiao, ChingYuan \& Pei-Yu Shih. 2015. "The Impact of Using Picture Books with Preschool Students in Taiwan on the Teaching of Environmental Concepts". Taiwan: International Education Studies. Vol. 8, No. 3.

Mueller, Stephanie. 2006. Panduan Belajar Membaca dengan Benda-Benda di Sekitar untuk Usia 3-8 Tahun. Jakarta: Erlangga.

Mitchell, D. 2003. Children's Literature an Imitation to the Word. Michigan State University.

Malu, F, Kathleen. 2013. "Exploring Children's Picture Storybooks with Adult and Adolescent EFL Learners". English Teaching Forum (3) 10-18.

Montag, et al. 2015. The Words Children Hear: Picture Books and the Statistics for Language Learning. Psychological Science, Vol. 26(9) 1489 -1496.

Nomleni, \& Manu. 2018. Pengembangan Media Audio Visual dan Alat Peraga dalam Meningkatkan Pemahaman Konsep dan Pemecahan Masalah. Scholaria: Jurnal Pendidikan dan Kebudayaan. 8(3) 219-230.

Nurgiyantoro, Burhan. 2013. Sastra Anak Pengantar Pengalaman Dunia Anak. Yogyakarta: Gajah Mada University Press.

Peraturan Pemerintah Republik Indonesia. 2005. Undang-undang nomor 19 tahun 2005 pasal 20 tentang Standar Nasional Pendidikan. Jakarta.

Retnowati, Giyati, Rose Mini Agoes Salim, Airin Yustikarini Saleh. 2018. Effectiveness of Picture Story Books Reading to Increase Kindness in Children Aged 5-6 years.

Suyanto, Slamet. 2005. Konsep Dasar Anak Usia Dini. Jakarta : Departemen Pendidikan Nasional.

Uno, Hamzah dan Lamatenggo, Nina. 2011. Teknologi Komunikasi \& Informasi pembelajaran. Jakarta: Bumi Aksara.

Van den Akker J., dkk. 2006. Educational Design Research. London and New York: Routledge. 